\title{
STUDI KAYU ANGIN (Usnea spp.) SEBAGAI BAHAN OBAT TRADISIONAL Studi Kasus: Pasar Tradisional Kota Jakarta
}

\author{
Miftahul Jannah $^{1}$, Nida Afifah ${ }^{1}$ \\ ${ }^{1}$ Jurusaan Biologi Fakultas Sains dan Teknologi Universitas Islam As-Syafi iyah \\ E-mail: mifta.frozi01@gmail.com
}

\begin{abstract}
Research into local community knowledge is very important to provide medicinal plant data and can be used as a basis for further research. Usnea is a genus of lichen that is used by Indonesian people in traditional medicine. The people knows Usnea as Kayu Angin. The aim of this study was to record the use of the species of the genus Usnea as traditional herbal medicines in Jakarta's tradisional market. The study was a part of a project called Hibah Dosen Pemula (PDP) RISTEKDIKTI. Respondents were interviewed using a semi-structured questionnaire . Data were descriptively analyzed based on exploration results and interviews with respondents. The result showed 14 species of Usnea had been founded and were used to treat different ailments. The collection of data and information about the use of Usnea in Jakarta's tradisional market was firstly recorded and expected could be enriched Usnea data from Java.
\end{abstract}

Keywords: biodiversity, Usnea, Jakarta, traditional medicine

\section{PENDAHULUAN}

$\mathrm{U}$

snea merupakan salah satu genus terbesar dari famili Parmeliaceae yang memilki distribusi luas di dunia, dengan jumlah spesies $\geq 600$ spesies (Hawksworth et al., 1995; Ohmura, 2001). Usnea memiliki banyak nama daerah seperti beard lichen atau old man`s beard (Eropa), tahi angin (Malaysia), kayu angin atau rasuk angin (Jawa Tengah dan Yogyakarta), tae angen (Madura), janggutan resi (Bali), jenggot cina (Jawa Timur), cirik angin (Sumatra-Minang ), gori ma iho, tai anging (Sulawesi), janggut ndurabin, janggut rabitson (Batak), dan janggot kai (Jawa Barat) (Heyne, 1987). Masyarakat Indonesia telah mengenal Usnea sebagai salah satu bahan ramuan pengobatan tradisional sejak lama. Kemampuan untuk meracik ramuan tradisonal ini diperoleh secara turun-temurun.

Obat tradisional menjadi salah satu pilihan masyarakat untuk pengobatan dan menjaga kondisi tubuh. Penggunaan obat tradisional seperti jamu masih sangat diminati masyarakat di kota besar. Hasil studi di pasar Jatinegara, Bandung dan Sukabumi ditemukan jenis Usnea terdapat dalam 27 racikan jamu (Noer, 2013), selain itu di Yogyakarta dan Surakarta, juga dimanfaatkan baik sebagai campuran racikan jamu maupun simplisia tunggal, yang digunakan untuk mengobati berbagai macam penyakit seperti peluruh air seni, masuk angin, darah tinggi, stroke, jantung, nyeri haid, pegel linu, dan batuk (Jannah, 2014). Hasil survey menunjukkan jenis yang berbeda terdapat 
dalam satu racikan jamu di pasar tradisional, setiap jenis Usnea mempunyai kandungan metabolit sekunder yang berbeda sehingga memiliki fungsi yang spesifik (Nayaka et al, 2010). Pemanfaatan yang tidak tepat akan memberikan hasil yang kurang maksimal dalam pengobatan.

Penelitian etnobotani tumbuhan yang diperdagangkan di pasar tradisional telah banyak dilakukan di beberapa Negara seperti di Ethiopia, Madagascar dan Ecuador (Randriamiharisoa et al., 2015; Kebede et al., 2016; Tinitana et al., 2016). Pengumpulan data dan informasi tentang penggunaan kayu angin sebagai bahan obat tradisional di pasar tradisional kota Jakarta pertama kali dilaporkan dan sangat perlu dilakukan. Hal tersebut, karena keberadaan pasar tradisional saat ini semakin terdesak dengan kehadiran pasar modern dan toko online. Padahal, pasar tradisional menjadi sumber pengetahuan lokal, khususnya yang terkait dengan penggunaan tumbuhan secara tradisional oleh masyarakat.

Hasil dari penelitian ini diharapkan mampu meluruskan dan memberikan input pada masyarakat mengenai jenis Usnea dan manfaatnya untuk bahan obat tradisional dan strategi konservasi secara tepat. Data jenis-jenis Usnea yang dimanfaatkan serta cara pemanfaatannya diperlukan untuk mendukung pengembangan bahan aku obat di Indonesia. Selain itu, juga dapat digunakan untuk memperkaya informasi dalam bidang farmasi serta penelitian lebih lanjut terkait formulasi obat.

\section{METODE PENELITIAN}

Survei dilakukan selama April-Juni 2019 di pasar tradisional kota Jakarta (Jatinegara, Senen, dan Keramat Jati), penjual jamu online, dan toko jamu. Informasi tentang kayu angin (Usnea) sebagian diperoleh dari LIPI, data penelitian sebelumnya, dan beberapa informasi diperoleh dari masyarakat setempat, terutama penjual jamu keliling.

Pengambilan sampel dilakukan dengan metode purposive sampling (Tiro, 2011). Data etnobotani diperoleh melalui observasi langsung yang didukung oleh wawancara. Sebanyak 25 responden diwawancarai yang terdiri dari pedagang jamu, peracik jamu (tabib), dan masyarakat. Wawancara dilakukan dalam panduan kuesioner semi-terstruktur (kuesioner sudah tervalidasi menggunakan validitas konten dengan penilaian ahli).

Informasi yang dikumpulkan meliputi jenis Usnea yang ditemukan (nama lokal), jenis Usnea yang digunakan oleh masyarakat, asal Usnea diambil, kegunaan dalam kehidupan sehari-hari, bagian-bagian yang digunakan, cara menggunakannya, dan asal informasi pengetahuan dalam memanfaatkan. Data dianalisis secara deskriptif berdasarkan hasil eksplorasi dan wawancara dengan masyarakat.

Sampel Usnea yang ditemukan selanjutnya dilakukan identifikasi berdasarkan karakter morfologis, anatomis, dan mikrokimia. Pengamatan karakter morfologi meliputi warna talus, bentuk talus, bentuk percabangan talus, sentral aksis, letak fibril, letak papillae, tipe dan warna medula, asesoris korteks, pseudocyphellae, foveoles, warna dan tipe soralia, warna dan tipe soredia, warna dan tipe isidia. Pengamatan anatomi dilakukan dengan mengamati irisan membujur talus bagian medulla dan sentral aksis. Pengamatan mikromia dilakukan dengan cara mengiris talus lichen dan dilihat perubahan warna pada bagian medula setelah ditetesi dengan Kaliumhydroxid Platzchen, dan Calcium Hypochlorite (Jannah et al, 2019). 


\section{HASIL DAN PEMBAHASAN}

Semakin berkembangnya pengobatan modern dan semakin mudahnya masyarakat mengakses fasilitas kesehatan mengakibatkan pengobatan tradisional mulai menurun pada beberapa daerah (Sujarwo, dkk, 2018), tetapi di kota Jakarta pemanfaatn tumbuhan sebagai obat tradisional masih diminati. Hal tersebut ditunjukkan dengan masih banyak ditemukan penjual jamu baik dalam bentuk racikan atau seduh yang memanfaatkan tumbuhan sebagai bahan dalam pembuatan obat tradisional.

Hasil penelitian menunjukkan sebanyak 14 spesies dari genus Usnea telah ditemukan di tiga pasar tradisonal kota Jakarta yaitu Jatinegara, Senen, dan Keramat Jati. Jenis-jenis Usnea yang ditemukan antara lain Usnea florida, U. pectinata, $U$. barbata, U. diffracta, U. fragilescens, $U$. intermedia, U. rubicunda, U. chaetophora, $U$. rubrotincta, $U$. subfloridina, $U$. hesperina, $U$. trichoides, $U$. flammea, dan $U$. pseudogatae. Berdasarkan hasil wawancara dengan informan kunci dijelaskan bahwa Usnea yang diperjualbelikan di ketiga pasar tradisional tersebut berasal dari kawasan Jawa Timur khususnya kota Kediri. Hal tersebut juga diperkuat dengan ditemukannya tulisan pada kemasan racikan jamu yang berlabel Jawa Timur, Kota Kediri.

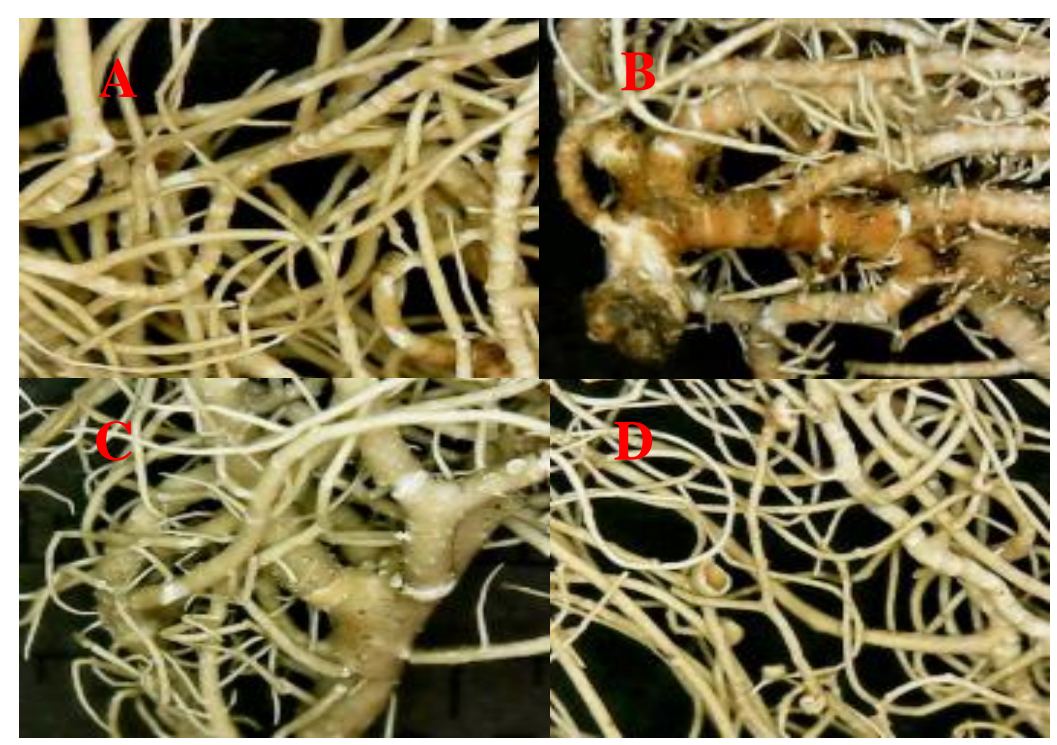

Gambar 1. Talus. A. Usnea diffracta, B. U. trichoides (sub genus Dolichousnea), C. U. fragilescens (sub genus Usnea), D. U. pectinata (sub genus Eumitria)

Usnea yang ditemukan terdiri dari dua sub genus yaitu sub genus Usnea dan sub genus Dolichousnea. Sub genus Usnea terdiri dari Usnea florida, U. articulata, U. barbata, U. fragilescens, U. intermedia, U. rubicunda, U. chaetophora, U. rubrotincta, $U$. subfloridina, U. hesperina, U. flammea, dan U. pseudogatae, sedangkan sub genus Dolichousnea terdiri dari $U$. diffracta dan $U$. trichoides, dan sub genus eumitria yaitu $U$. pectinata (Gambar 1). Karakter utama genus Usnea yaitu talus tipe fruticose, percabangan dengan setral aksis yang bersifat kartilaginosa, dan mengandung asam usnic di dalam korteks. Setiap spesies dalam genus Usnea dapat dibedakan berdasarkan karakter seperti morfologi talus, apotesia, tipe pertumbuhan, tipe percabangan, pangkal talus, tipe medula, pigmen di sekitar medula dan korteks, tipe dan warna sentral aksis, apotesia, organ vegetatif paling dominan, pseudochyphellae, foveoles, fibril, 
isidiomorph, papillae, uji mikrokimia, dan kandungan substansi Usnea. Karakter diagnostik sub genus Dolichousnea yaitu kehadiran annular-pseudochyphellae, sedangkan pada sub genus Usnea yaitu sentral aksis tipe solid.

Tabel 1. Jenis-jenis Usnea yang ditemukan dan Pemanfaatannya

\begin{tabular}{|c|c|c|c|}
\hline No & Nama Spesies & Pemanfaatan & Lokasi \\
\hline 1 & Usnea florida & $\begin{array}{l}\text { asam urat,Jantung, stroke,liver, ginjal, } \\
\text { mandi uap,masuk angin }\end{array}$ & Jatinegara, Kramat Jati \\
\hline 2 & U. pectinata & $\begin{array}{l}\text { asam urat, asma atau paru-paru } \\
\text { Kencing manis pondok gede. habis } \\
\text { bersalin, masuk angin }\end{array}$ & Jatinegara, Kramat Jati \\
\hline 3 & U. barbata & $\begin{array}{l}\text { mandi uap, liver, ginjal, jamu } \\
\text { kesehatan, habis bersalin, masuk angin }\end{array}$ & Kramat Jati, Jatinegara \\
\hline 4 & U. diffracta & $\begin{array}{l}\text { asam urat, kencing manis, jamu } \\
\text { kesehatan, habis bersalin, gejala } \\
\text { masuk angin }\end{array}$ & Jatineagara, Pasar Senen \\
\hline 5 & U. fragilescens & $\begin{array}{l}\text { mandi uap, jamu kesehatan, masuk } \\
\text { angin }\end{array}$ & Pasar Senen \\
\hline 6 & U. intermedia & jamu kesehatan & Pasar Senen, Kramat Jati \\
\hline 7 & U. rubicunda & $\begin{array}{l}\text { campuran bahan pengobatan Semua } \\
\text { penyakit }\end{array}$ & Jatinegara, Pasar Senen \\
\hline 8 & U. chaetophora & $\begin{array}{l}\text { campuran bahan pengobatan semua } \\
\text { penyakit }\end{array}$ & Jatinegara, Pasar Senen \\
\hline 9 & U. rubrotincta & $\begin{array}{l}\text { campuran bahan pengobatan semua } \\
\text { penyakit }\end{array}$ & Jatinegara \\
\hline 10 & U. subfloridina & $\begin{array}{l}\text { campuran bahan pengobatan semua } \\
\text { penyakit }\end{array}$ & Jatinegara \\
\hline 11 & U. hesperina & $\begin{array}{l}\text { campuran bahan pengobatan semua } \\
\text { penyakit }\end{array}$ & Jatinegara \\
\hline 12 & U. trichoides & $\begin{array}{l}\text { campuran bahan pengobatan semua } \\
\text { penyakit }\end{array}$ & Jatinegara \\
\hline 13 & U. flammea & $\begin{array}{l}\text { campuran bahan pengobatan semua } \\
\text { penyakit }\end{array}$ & Jatinegara \\
\hline 14 & U. pseudogatae & $\begin{array}{l}\text { campuran bahan pengobatan semua } \\
\text { penyakit }\end{array}$ & Jatinegara \\
\hline
\end{tabular}

Masyarakat kota Jakarta memanfaatkan Usnea untuk mengobati berbagai macam penyakit baik sebagai simplisia tunggal maupun dicampurkan dengan bahan lain. Pemanfaatan dengan pencampuran bahan lain memerlukan campuran bahan lainnya yang memiliki efek sinergis dalam pengobatan suatu penyakit. Pemanfaatan Usnea dalam bentuk simplisia tunggal hanya digunakan untuk mengobati masuk angin. Masyarakat pada umumnya mendapatkan informasi bahwa Usnea berkhasiat sebagai obat dari pengalaman secara turun-temurun dari orang-orang yang terdahulu. Hal tersebut mengakibatkan banyak ditemukan spesies Usnea yang berbeda ditemukan dalam satu racikan jamu. Selain itu, Usnea juga ditemukan dalam semua racikan jamu. Peracik jamu mengemukakan bahwa Usnea merupakan bahan utama yang harus ada dalam racikan jamu. Masyarakat menggunakan Usnea untuk penambah stamina, mandi uap, menambah nafsu makan, asam urat, jantung, stroke, liver, ginjal, asma, paru-paru, kencing manis, habis bersalin, masuk angin, kanker, dan bahan campuran pengobatan semua penyakit (Gambar 2). Hal tersebut hampir sama dengan pemanfaatan Usnea oleh 
masyarakat sunda sebagai jamu sariawan, disentri, masuk angin, erupsi kulit, kaku, nyeri haid, wasir, ibu melahirkan, dan bahan bedak wanita bangsawan (Noer, dkk, 2015).

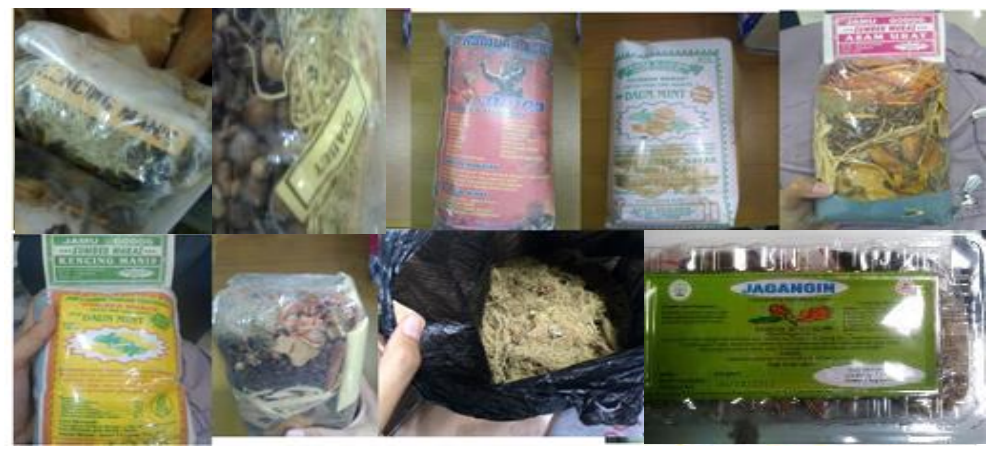

Gambar 2. Pemanfaatan Usnea dalam Produk Jamu Tradisional

Kayu angin juga digunakan untuk campuran obat luar dan kosmetik dalam, seperti jerawat, penghalus kulit, pengencang kulit, obat luka-luka, kudis, gatal-gatal dan sebagai pelancar peredaran darah, sedangkan untuk campuran obat tradisional dalam untuk bedak kulit yang dapat membuat kulit tampak segar berseri-seri dan cerah (Hutapea, J., dkk, 1992). Selain itu, Usnea juga ditemukan sebagai salah satu bahan produk Obat Herbal Terstandar (OHT) seperti tolak angin, janna tea hot, campuran madu al habibi dan herbaskin (Gambar 3). Usnea bisa digunakan untuk mengobati berbagai macam penyakit, karena mengandung berbagai macam metabolit sekunder. Setiap spesies Usnea mengandung perbedaan kandungan metabolit sekunder yang spesifik. Kandungan metabolit sekunder seperti lecanoric acid, dan usnic acid dimanfaatkan untuk antioksidan, antimikroba dan induksi apoptosis pada sel kanker (Luo, 2009; Backorova, 2012). Selain itu, usnic acid juga bisa digunakan untuk bahan pengawet.

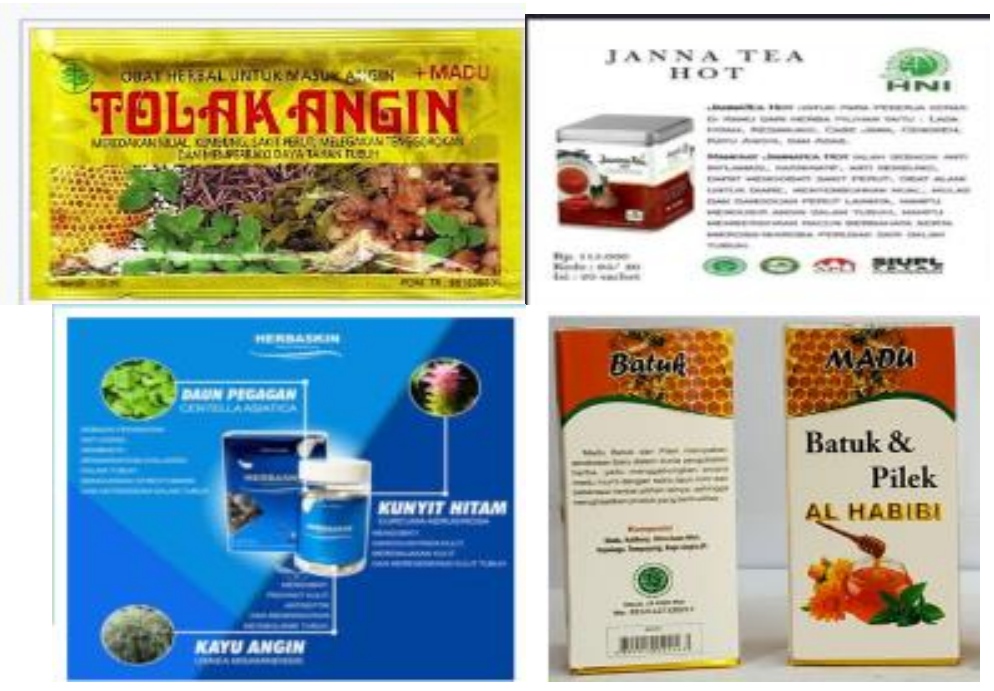

Gambar 3. Pemanfaatan Usnea dalam Berbagai Produk Obat Herbal Terstandar (OHT) Dan Kecantikan

Permasalahan penting yang perlu diperhatikan adalah semakin berkurangnya populasi Usnea di hutan, akibat dari pengambilan Usnea secara terus menerus oleh 
masyarakat dalam jumlah besar, termasuk spesies yang tidak memiliki khasiat secara spesifik bagi pengobatan. Sampai saat ini di Indonesia belum diketahui adanya usaha budidaya Usnea, sehingga upaya pelestariannya perlu segera dilakukan. Penelitian mengenai kultur lichen untuk diproduksi secara masal masih dikembangkan di negara Australia, sedangkan di negara lain khususnya Indonesia belum dikembangkan. Pada prinsipnya teknik kultur jaringan untuk lichen hampir sama dengan tanaman lain dengan menggunakan kombinasi medium jamur dan alga (Nash, 2008). Hal tersebut sangat memungkinkan untuk diterapkan di Indonesia sebagai tindakan konservasi yaitu memanfaatkan dan sekaligus memelihara keberadaan lichen. Selain itu pelestarian in situ juga bisa dilakukan dengan upaya pelestarian tumbuhan yang menjadi inang, ini merupakan salah satu alternative yang bisa dikembangkan selain cara diatas.

\section{KESIMPULAN}

Hasil penelitian menunjukkan sebanyak 14 spesies dari genus Usnea telah ditemukan di pasar tradisonal kota Jakarta Usnea yang tebagai dalam 3 sub genus yaitu Usnea, Dolichousnea, dan Eumitria, dalam produk jamu tradisional yang dimanfaatkan masyarakat untuk pengobatan berbagai macam penyakit. Hasil penelitian ini diharapkan dapat melengkapi data etnobotani Usnea di Indonesia. Penelitian ini juga diharapkan dapat menjadi rujukan dalam strategi nasional konservasi sumber daya plasma nutfah Usnea. Saran peneliti untuk studi lebih lanjut, perlu segera dilakukan cara budidaya Usnea, terutama spesies yang banyak dimanfaatkan dalam pengobatan, sehingga kelestariannya dapat terus terjaga.

\section{UCAPAN TERIMAKASIH}

Penulis mengucapkan terima kasih kepada KEMENRISTEKDIKTI yang telah mendanai secara penuh penelitian in. Selain itu juga kepada Siti Zainab, S.Si. dan Anisa Rahmawati yang berperan sebagai asisten lapangan dan laboratorium yang telah membantu penelitian ini.

\section{DAFTAR PUSTAKA}

Backorova, M., R, Jendzelovsky, M., Kello, Backor, M., J, Mikes, Fedorocko,P. 2012. Lichen secondary metabolites are responsible for induction of apoptosis in HT-29 and A2780 human cancer cell lines. Toxicology In Vitro (3). DOI:10.1016/j.tiv.2012.01.017

Hawksworth, D.L; Krik, P.M.; Sutton, B.C. \& Pelger, D.N. 1995. Ainsworth \& Bisby`s Dictionary of the Fungi. CAB International, Cambridge University Press/. Wallingford.

Heyne, K. 1987. Tumbuhan Berguna Indonesia 1. Jakarta: Yayasan Sarana Wana Jaya.

Hutapea, J., Yulia, W., Soerahso. 1992. Ragam Penggunaaan Kayu Angin Sebagai Obat Luar dan Kosmetika Dalam Obat Tradisional. Warta Tumbuhan Obat Indonesia (1) 4.

Jannah, M. 2014. Variasi Genetik dan Identifikasi Usnea spp. Berdasarkan Karakter Morfologis dan Molekular.Tesis.Universitas Gadjah Mada.

Jannah, M., Rahayu, D.A., Saptasari, M., Untari, L.F. 2019. The Fruticose Lichens in the Forest Tahura (Taman Hutan Raya) R. Soeryo, East Java. Biotropika: Journal of Tropical Biology (7) 2. DOI: http://dx.doi.org/10.21776/ub.biotropika.2019.007.02.3 
Kebede, A., Ayalew S., Mesfin A., and Mulualem G., 2016. Ethnobotanical investigation of traditional medicinal plants commercialized in the markets of Dire Dawa City, Eastern Ethiopia. Journal of Medicinal Plants Studies, 4(3), pp. 170-178.

Luo, H.,Yamamoto, E.Y., Kim, E.J, Sung Jung, J., Koh, Y.J., \& Hur, J.S., 2009. Lecanoric acid, a secondary lichen substance with antioxidant properties from Umbilicaria antarctica in maritime Antarctica (King George Island). Pilar Bio. 32: 1033-1040. DOI 10.1007/s00300-009-0602-9.

Nayaka, S.; Upreti, D.K, Khare, R. 2010. Medicinal Lichens of India. Lichenology Laboratory, National Botanical Research Institute (CSIR).

Nash, H.T. 2008. Lichen Biology second edition. Arizona: Cambridge University Press.

Noer, I.S., Ramlan, A., Subarnas, A., Sutedja, E. 2013. Karakterisasi dan Kekerabatan Janggot Kai (Usnea spp.) di Priangan. IJAS (3)2. DOI : https://doi.org/10.24198/.v3i2.16833.

Noer, I.S., Maryawati, B., Maryani, L., Juanda, J., Manganti, A. 2015. Etnolichenology of Old Mens Beard (Usnea spp.) at Priangan. 2015. Prosiding of The 3rd International Conference on Biological Science 2013 (The 3rd ICBS-2013). ISSN 2413-0877 (2).

Ohmura, Y. 2001. Taxonomic Study of The Genus Usnea (Lichenized Ascomycetes) In Japan and Taiwan. The Journal of the Hattori Botanical Laboratory. 90 (1-96).

Randriamiharisoa, M.N., Kuhlman A.R., Jeannoda V., Rabarison H., Rakotoarivelo N., Randrianarivony T., Raktoarivony F., Randrianasolo A. and Bussmann R.W., 2015. Medicinal plants sold in the markets of Antananarivo, Madagascar. Journal of Ethnobiology and Ethnomedicine, 11(60), pp. 112.DOI:10.1186/s13002-015-0046-y.

Sujarwo, W., Lugrayasa, I.N., Kuswantoro, F. 2019. Studi Etnobotani Tiga Pasar Tradisional di Kabupaten Tatanan Bali. Berita Biologi (17) 3. DOI: 10.14203/beritabiologi.v17i3.3342.

Tinitana, F., Rios M., Romero-Benavides J.C., de la Cruz Rot M. and Pardo-de-Santayana M. 2016. Medicinal plants sold at traditional markets in Southern Ecuador. Journal of Ethnobiology and Ethnomedicine, 12(29), pp. 1-18. DOI 10.1186/s13002-016-0100-4.

Tiro, M. A. \& Arbianingsih. (2011). Teknik Pengambilan Sampel. Andira Publisher, Makassar. 